\title{
Prospective Comparative Study of Prevalence of Vitamin D3 Deficiency in First Trimester Pregnancy in Urban and Rural Areas
}

\author{
Sumant Shah (M.S) ${ }^{1}$, Vinkal Ladani ${ }^{2}$, Vishrut Shah M.B.B.S ${ }^{3}$, \\ ${ }^{1}$ Professor and Head of department, Department of Obstetrics and Gynaecology, Civil hospital, Ahmedabad, India \\ ${ }^{2}$ Resident Doctor, Department of Obstetrics and Gynaecology, Civil hospital, Ahmedabad, India \\ ${ }^{3}$ N.H.L Municipal College, Ahmedabad, India
}

Corresponding Author: Vinkal Ladani (Resident doctor), Department of Obstetrics and Gynaecology, B.J medical college and civil hospital, Ahmedabad, Email: ladani.vinkal@gmail.com Phone: 9099088483

\begin{abstract}
Introduction: Vitamin D3 deficiency during pregnancy may have a negative effect on both mother and child. The aim of the present study is to do a comparative study of prevalence of vitamin D3 deficiency during first trimester of pregnancy in Indian women in urban and rural areas and to decide if vitamin D3 supplementation is needed in pregnancy. Materials and methods: Prospective comparative study of prevalence of vitamin $D 3$ deficiency in first trimester pregnancy in urban and rural areas was carried out at $B$. $J$ medical college from January 2016 to January 2017. Blood samples of urban women from Ahmedabad civil hospital were collected routinely for screening for serum Vitamin D3 during first trimester of pregnancy and blood samples of rural women were collected from Kavitha village of Ahmedabad district. The serum concentrations of vitamin D3 were analysed by the High Performance Liquid Chromatography. Results: In $84 \%$ of the study population ( $N=50)$, vitamin D3 concentrations were below 30 ng/ml, which is attributed to an insufficient status. 6\% of population had vitamin D3 concentrations below 10ng/ml. Among total population, the mean vitamin D3 level was $21.21 \mathrm{ng} / \mathrm{ml}$. In 100\% of the urban study population $(\mathrm{N}=25)$, vitamin D3 concentrations were below 30ng/ml. 8\% of urban study population vitamin D3 concentrations were below $10 \mathrm{ng} / \mathrm{ml}$ which is attributed to a deficient status. Among urban population, the mean vitamin D3 level was 18.48ng/ml.In $68 \%$ of the rural population $(N=25)$, vitamin D3 concentrations were below 30 ng/ml and $8 \%$ of rural study population had vitamin D3 concentrations below $10 \mathrm{ng} / \mathrm{ml}$. Among total rural population, the mean vitamin D3 level was $23 \mathrm{ng} / \mathrm{ml}$. This shows that in rural population vitamin D3 level was higher as compared to urban population. Conclusion: A high prevalence of vitamin $D$ deficiency was observed in early pregnancy in urban population which was related to education, occupation, diet, dressing habit, parity, use of multi-vitamins and season at sampling. However the study is limited considering only prevalence of vitamin $D$ deficiency and a longer and detailed follow up is required to assess the effect on maternal and neonatal outcome. Clinical Relevance: This shows significant deficiency of vitamin $D 3$ in pregnancy, especially in urban women. The women should receive nutritional and general pregnancy counselling and more attention should be given for vitamin D supplementation.
\end{abstract}

Keywords: Vitamin D3; pregnancy outcome; vitamin D3 deficiency, first trimester pregnancy, Rural, Urban

\section{Introduction}

Vitamin D is a secosteroid and the most significant source is direct exposure of the skin to sunlight. It can also be obtained from dietary sources, nutritional supplementation and food fortification. ${ }^{[1]}$ Vitamin D deficiency (VDD) is identified as a public health problem in many countries, and pregnant women have been identified as a high-risk group, among whom the prevalence of VDD ranges between 20 and $40 \% .{ }^{[2]}$ Vitamin D3 deficiency during pregnancy may have a negative impact on both mother and child. ${ }^{[3]}$ In the first trimester, the foetus accumulates $2-3 \mathrm{mg}$ /day of calcium in the skeleton, which doubles in the last trimester. ${ }^{[4]}$ The aim of the present study is to do comparative study of prevalence of vitamin D3 concentrations during first trimester of pregnancy in Indian women in urban and rural areas and to decide if vitamin D3 supplementation is needed in pregnancy. As there is less exposure of sunlight in community living in urban areas as compared to community living in rural areas because of life style, crowded residence and type of housing available.

\section{Objective}

To assess serum levels of 25-hydroxyvitamin $\mathrm{D}[25(\mathrm{OH}) \mathrm{D}]_{3}$ in the first trimester in rural and urban pregnant females, determine the prevalence of deficiency in both population and assess factors affecting serum vitamin $\mathrm{D}_{3}$ levels.

\section{Materials and Methods}

A total of 50 pregnant females were studied from January 2016 to January 2017 which consisted of 25 from urban area who visited Ahmedabad civil hospital OBGY department OPD during first trimester of pregnancy (9th - 12th gestational weeks) and 25 from rural area of Kavitha village having 30,000 population. Data on season and gestational age at sampling, maternal age, parity, numbers of earlier gestations and spontaneous abortions, maternal BMI, and smoking was obtained from case paper of women coming to hospital.This study was approved by the Ethics Committee of our hospital. All participants were informed about the purpose of the study and requested to participate after giving written consent. They were asked to complete a questionnaire that included the characteristics of their pregnancy and information about the factors associated with vitamin D status. Non-fasting blood samples were taken and analysed for $25(\mathrm{OH}) \mathrm{D}_{3}$ levels. Only singletons pregnancywho had no GDM or history of diabetes mellitus and blood pressure $<140 / 90 \mathrm{mmHg}$ or no preeclampsia were included. Patients smaller for gestational ages $(<5$ th percentile), smokers or having any systemic disease or those taking medications affecting vitamin D medications were 


\section{International Journal of Science and Research (IJSR) \\ ISSN (Online): 2319-7064}

Index Copernicus Value (2015): 78.96 | Impact Factor (2015): 6.391

excluded. Data collected consisted of age, parity, BMI, type of diet, education, occupation, gestation age at serum collection, mean BP, blood sugar level, dressing habit and history of multivitamin intake. The serum concentrations of vitamin D3 were analysed by the High Performance Liquid Chromatography using coulometric electrode array detector (HPLC-CEAD) method in the biochemistry laboratory from civil hospital, Ahmedabad. Microsoft Excel version 13.0 is used to perform the statistical analysis.Although there is no fixed criteria regarding the optimal $25(\mathrm{OH}) \mathrm{D}$ level, vitamin D levels were categorized into groups as serum $25(\mathrm{OH}) \mathrm{D}$ levels $<10 \mathrm{ng} / \mathrm{mL}$, between $10-30 \mathrm{ng} / \mathrm{mL}$ and $30-100$ $\mathrm{ng} / \mathrm{mL}$, indicating deficient, insufficient and sufficient vitamin D level respectively ${ }^{[6]}$. Data was represented as mean \pm standard deviation (SD) and as percentages for categorical variables and tabulated comparing urban and rural groups.

\section{Risk factors for Vitamin D deficiency}

The main source of Vitamin D for children and adults is sunlight, so the main cause of VDD is the decrease of its production by body. Any factor that affects the transmission of UVB radiation or interferes with its skin penetration will affect the production of vitamin D. ${ }^{[5]}$. Among these risk factors are:Use of sunscreen with a protection factor of 30 reduces the synthesis of Vitamin D in the skin, above $95 \%$. Individuals with darker skin have natural sun protection, as melanin absorbs UVB radiation, and thus they need 3-5 times longer sun exposure to synthesize the same amount of Vitamin D than individuals with light skin. Skin aging as well as age decrease the capacity of the skin to produce Vitamin D due to lower availability of 7-dehydrocholesterol. The second cause is the reduced intake of Vitamin D, as few foods contain high quantities of it (blue fish, egg yolks). The intake of the vitamin can be increased with fortified products such as dairy products, although the amount of Vitamin D they provide may be insufficient for an adequate state of ViD. $^{[7]}$ In severe liver failure, chronic granulomatous disease, certain lymphomas and primary hypoparathyroidism, patients have increased metabolism of $25(\mathrm{OH}) \mathrm{D}$ into $1.25(\mathrm{OH}) 2 \mathrm{D}$, and thus a high risk of VDD. ${ }^{[7]}$

\section{Results and Discussion}

Table 1: Characteristics of the Study Population

\begin{tabular}{|c|c|}
\hline Age & $23.5 \pm 4$ years \\
\hline Parity n, $\%$ & \\
\hline -nulligravida & $24(48 \%)$ \\
\hline -multigravida & $26(52 \%)$ \\
\hline Body mass index & $22.5 \pm 4$ \\
\hline Diet n.\% & \\
\hline -non vegetarian & $14(28 \%)$ \\
\hline -vegetarian & $36(72 \%)$ \\
\hline Education n, & \\
\hline -no formal education & $37(74 \%)$ \\
\hline -finished high school & $10(20 \%)$ \\
\hline -post graduation & $3(6 \%)$ \\
\hline Occupation n,\% & \\
\hline -unemployed & $34(68 \%)$ \\
\hline -unskilled work & $11(22 \%)$ \\
\hline -skilled work & $05(10 \%)$ \\
\hline
\end{tabular}

\begin{tabular}{|l|c|}
\hline Gestational age at serum collection & $10.5 \pm 2$ weeks \\
\hline Season - winter & $50(100 \%)$ \\
\hline Mean systolic BP & $110 \mathrm{~mm} \mathrm{hg}$ \\
\hline Mean diastolic BP & $70 \mathrm{~mm} \mathrm{hg}$ \\
\hline Random blood sugar level & $78 \mathrm{mg} / \mathrm{dl}$ \\
\hline Maternal multivitamin use n, $\%$ & \\
\hline -yes & $31(62 \%)$ \\
\hline -no & $19(38 \%)$ \\
\hline Consumption of dairy products n, $\%$ & $19(38 \%)$ \\
\hline -sufficient & $31(62 \%)$ \\
\hline -insufficient & \\
\hline Dressing habit n, $\%$ & $33(66 \%)$ \\
\hline -covered & $17(34 \%)$ \\
\hline -uncovered &
\end{tabular}

Table 2: Association of Serum Vitamin D3 Levels and Characteristics Of Study Population:

\begin{tabular}{|c|c|c|c|}
\hline & $<10 \mathrm{ng} / \mathrm{ml}$ & $10-30 \mathrm{ng} / \mathrm{ml}$ & $>30 \mathrm{ng} / \mathrm{ml}$ \\
\hline Age & $23.5 \pm 4$ years & $23.5 \pm 4$ years & $23.5 \pm 4$ years \\
\hline $\begin{array}{c}\text { Parity Urban area: } \\
\text {-primigravida } \\
\text {-multigravida }\end{array}$ & $\begin{array}{c}0 \\
1(4 \%)\end{array}$ & $\begin{array}{l}10(40 \%) \\
14(56 \%)\end{array}$ & $\begin{array}{l}0 \\
0\end{array}$ \\
\hline $\begin{array}{c}\text { Rural area: } \\
\text {-primigravida } \\
\text { - multigravida }\end{array}$ & $\begin{array}{c}0 \\
1(4 \%)\end{array}$ & $\begin{array}{l}7(32 \%) \\
9(36 \%)\end{array}$ & $\begin{array}{c}7(32 \%) \\
1(4 \%)\end{array}$ \\
\hline Body mass index & $22.5 \pm 4$ & $22.5 \pm 4$ & $22.5 \pm 4$ \\
\hline $\begin{array}{c}\text { Diet Urban area: } \\
\text {-non vegetarian } \\
\text {-vegetarian }\end{array}$ & $\begin{array}{c}0 \\
2(8 \%)\end{array}$ & $\begin{array}{c}5(20 \%) \\
18(72 \%)\end{array}$ & $\begin{array}{l}0 \\
0\end{array}$ \\
\hline $\begin{array}{c}\text { Rural area: } \\
\text {-non vegetarian } \\
\text {-vegetarian }\end{array}$ & $\begin{array}{c}0 \\
1(4 \%)\end{array}$ & $\begin{array}{c}3(12 \%) \\
13(42 \%)\end{array}$ & $\begin{array}{c}6(24 \%) \\
2(8 \%)\end{array}$ \\
\hline $\begin{array}{c}\text { Education } \\
\text { Urban area: } \\
\text {-non formal } \\
\text {-high school } \\
\text {-post graduation } \\
\text { Rural area: } \\
\text {-non formal } \\
\text {-high school } \\
\text {-post graduation }\end{array}$ & $\begin{array}{c}0 \\
1(4 \%) \\
1(4 \%) \\
\\
0 \\
0 \\
1(4 \%)\end{array}$ & $\begin{array}{c}1(4 \%) \\
3(12 \%) \\
19(76 \%) \\
\\
13(42 \%) \\
3(12 \%) \\
0\end{array}$ & $\begin{array}{c}0 \\
0 \\
0 \\
5(20 \%) \\
3(12 \%) \\
0\end{array}$ \\
\hline $\begin{array}{c}\text { Occupation Urban area: } \\
\text {-housewife } \\
\text {-unskilled work } \\
\text {-skilled work } \\
\text { Rural area: } \\
\text {-housewife } \\
\text {-unskilled work } \\
\text {-skilled work } \\
\end{array}$ & $\begin{array}{c}2(8 \%) \\
0 \\
0 \\
1(4 \%) \\
0 \\
0 \\
\end{array}$ & $\begin{array}{c}18(72 \%) \\
0 \\
5(20 \%) \\
\\
13(42 \%) \\
3(12 \%) \\
0 \\
\end{array}$ & $\begin{array}{c}0 \\
0 \\
0 \\
\\
0 \\
8(32 \%) \\
0 \\
\end{array}$ \\
\hline Mean systolic BP & $110 \mathrm{mmHg}$ & $110 \mathrm{mmHg}$ & $110 \mathrm{mmHg}$ \\
\hline Mean diastolic BP & $70 \mathrm{mmHg}$ & $70 \mathrm{mmHg}$ & $70 \mathrm{mmHg}$ \\
\hline Blood sugar level & $78 \mathrm{mg} / \mathrm{dl}$ & $78 \mathrm{mg} / \mathrm{dl}$ & $78 \mathrm{mg} / \mathrm{dl}$ \\
\hline $\begin{array}{c}\text { Multivitamin intake } \\
\text { Urban area: } \\
\text {-yes } \\
\text {-no } \\
\text { Rural area: } \\
\text {-yes } \\
\text {-no } \\
\end{array}$ & $\begin{array}{c}0 \\
2(8 \%) \\
0 \\
0 \\
1(4 \%) \\
\end{array}$ & $\begin{array}{c}15(60 \%) \\
8(32 \%) \\
10(40 \%) \\
6(24 \%) \\
\end{array}$ & $\begin{array}{c}0 \\
0 \\
6(24 \%) \\
2(8 \%) \\
\end{array}$ \\
\hline $\begin{array}{c}\text { Dairy product intake } \\
\text { Urban area: } \\
\text {-sufficient } \\
\text {-insufficient } \\
\text { Rural area: }\end{array}$ & $\begin{array}{c}0 \\
1(4 \%)\end{array}$ & $\begin{array}{c}5(20 \%) \\
19(76 \%)\end{array}$ & $\begin{array}{l}0 \\
0\end{array}$ \\
\hline
\end{tabular}




\section{International Journal of Science and Research (IJSR) \\ ISSN (Online): 2319-7064}

Index Copernicus Value (2015): 78.96 | Impact Factor (2015): 6.391

\begin{tabular}{|c|c|c|c|}
\hline -sufficient & 0 & $6(24 \%)$ & $8(32 \%)$ \\
-insufficient & $1(4 \%)$ & $10(40 \%)$ & 0 \\
\hline Dressing habits Urban & & & \\
area: & $2(8 \%)$ & $13(42 \%)$ & 0 \\
-covered & 0 & $10(40 \%)$ & 0 \\
-uncovered & & & \\
Rural area: & $1(4 \%)$ & $16(64 \%)$ & $1(8 \%)$ \\
-covered & 0 & 0 & $7(32 \%)$ \\
-uncovered & \multicolumn{2}{|r}{} \\
\hline
\end{tabular}

Table 1 shows study population characteristics and its component. Vitamin D3 concentrations sampled during first trimester of pregnancy. Most samples were obtained at 5$12^{\text {th }}$ gestational week mostly during winter. In $84 \%$ of the study population $(\mathrm{N}=50)$, vitamin $\mathrm{D} 3$ concentrations were below $30 \mathrm{ng} / \mathrm{ml}$, which is attributed to an insufficient status. The population $6 \%$ had vitamin D3 concentrations below $10 \mathrm{ng} / \mathrm{ml}$, which is attributed to a deficient status and only 16 $\%$ had values greater than $30 \mathrm{ng} / \mathrm{ml}$, which represents sufficiency. Among total population, the mean vitamin D3 level was $21.21 \mathrm{ng} / \mathrm{ml}$. Vitamin D status from urban and rural population was compared. In $100 \%$ of the urban study population $(\mathrm{N}=25)$, vitamin $\mathrm{D} 3$ concentrations were below $30 \mathrm{ng} / \mathrm{ml}$, which is attributed to an insufficient status. The population $8 \%$ had vitamin D3 concentrations below $10 \mathrm{ng} / \mathrm{ml}$, which is attributed to a deficient status. Among total urban population, the mean vitamin D3 level was $18.48 \mathrm{ng} / \mathrm{ml}$.

In $68 \%$ of rural study population $(\mathrm{N}=25)$, vitamin D3 concentrations were below $30 \mathrm{ng} / \mathrm{ml}$, which is attributed to an insufficient status. The population $4 \%$ had vitamin D3 concentrations below $10 \mathrm{ng} / \mathrm{ml}$, which is attributed to a deficient status and $32 \%$ had values greater than $30 \mathrm{ng} / \mathrm{ml}$, which represents sufficiency. Among total rural population, the mean vitamin D3 level was $23 \mathrm{ng} / \mathrm{ml}$. This shows that in rural population had higher vitamin D3 level as compared to urban population.

We compared relation of vitamin D level and parity in urban and rural areas. It shows more deficiency in multigravida as compared to primigravida and more in urban area as compared to rural area. Relation of diet (Non vegetarian vs. vegetarian) and vitamin D3 level was compared. It shows more insufficiency in vegetarian as compared to nonvegetarian and more in urban area as compared to rural area. In relation to occupation, there is more insufficiency in housewife and skilled workers as compared to unskilled workers and more in urban area as compared to rural area.

In relation to education, there is inverse relationship between vitamin D3 level and education most probably due to more indoor work in educated person. In relation to dairy product intake, there is more insufficiency of vitamin D3 level people who take insufficient dairy product intake and more in urban area as compared to rural area. In relation to dressing habits, insufficiency of vitamin D3 is more in people who wear covered clothes and more in urban area as compared to rural area. We also compared the groups and found no significant differences between the groups concerning maternal age, BMI values, blood sugar levels, systolic and diastolic blood pressures at the baseline study visit and gestational age at serum collection. First trimester

vitamin D3 levels were not associated with the gestational age at birth in women who delivered after term pregnancy, with the mode of delivery, foetal sex, birth weight, or duration of hospital stay after birth (data not shown).

This study showed that most of the Indian pregnant women with uncomplicated pregnancy were vitamin D3 deficient or insufficient in the first trimester, with only a few (16\%) having sufficient ( $>30 \mathrm{ng} / \mathrm{ml}$ ) vitamin D concentrations. The factors associated with maternal vitamin D3 concentrations were sampling season, education, diet, dressing habits and maternal age, parity, residentialarea, occupation.

The Women should receive nutritional and general pregnancy counselling, we should pay more attention to vitamin D supplementation. All the factors should be taken into account by advising and encouraging, according to the individual food tolerance, to increase the intake of natural occurring vitamin D rich foods (fatty fish, mushrooms, eggs) or vitamin D fortified foods, regular supplementation and sun bathing whenever is possible.

\section{Conclusion and Implications}

We conclude that higher prevalence of vitamin D deficiency observed in urban population was related to dressing habit, occupation, diet especially dairy products intake and more indoor work. More large multicentre clinical trials are necessary to establish the vitamin D clinical involvement in human health and disease. The present study adds to current scientific information regarding prevalence of vitamin D deficiency in apparently healthy pregnant women. However the study is limited considering only prevalence of vitamin $\mathrm{D}$ deficiency and a longer and detailed follow up is required to assess the effect on maternal and neonatal outcome.

\section{References}

[1] Summary of the role of vitamin D in human metabolic processes. Available from http://www.fao.org/docrep/004/y2809e/y2809e0e.htm

[2] Mulligan ML, Felton SK, Riek AE, Bernal-Mizrachi C. Implications of vitamin D deficiency in pregnancy and lactation. Am J Obstet Gynecol. 2010; 202:429.e1-9.

[3] Dawodu A, Wagner CL. Prevention of vitamin D deficiency in mothers and infants worldwide - a paradigm shift. PaediatrInt Child Health. 2012;32:3-13

[4] Mulligan ML, Felton SK, Riek AE, Bernal-Mizrachi C. Implications of vitamin D deficiency in pregnancy and lactation. Am J Obstet Gynecol. 2010;202:429.e1-9

[5] Chicote CC, Lorencio FG; Comité de Comunicación de la Sociedad Española de Bioquímica Clínica y Patología Molecular. Vitamina D: unaperspectiva actual. Barcelona: Comité de Comunicación de la Sociedad Española de Bioquímica Clínica y Patología Molecular; 2013.

[6] Ross AC, Manson JE, Abrams SA, Aloia JF, Brannon PM, Clinton SK, et al. The 2011 report on dietary reference intakes for calcium and vitamin $\mathrm{D}$ from the institute of medicine: what clinicians need to know. J Clin Endocrinol Metab. 2011; 96:53-8.

[7] Holick MF. Vitamin D deficiency. N Engl J Med. 2007; 357:266-81.

\section{Volume 6 Issue 7, July 2017 www.ijsr.net}

